\title{
The stuff we don't do
}

\author{
It's time for a life lesson.
}

$\mathrm{D}$ ear Uncle Michael, thanks so much for taking me for a spin in the time machine! What a great way to spend my sixteenth birthday. It was honestly better than a new car. Versailles and the Mars launch and the flock of velociraptors - I just can't pick which was the best. They were all the best. Being able to watch Grandma play her favourite Aho symphony before the Minnesota Orchestra broke up. Breathing in the scent of fourth-century Beijing. It was all so amazing, so carefully chosen - almost more of a cultural festival than a birthday. It was like a liberal-arts education with strawberry gelato at the end. I've learned so much from you about space, time and the Novikov self-consistency principle in the years since Mum and Dad disappeared and Uncle John died. I really appreciate it.

You may have noticed by now that the trigger device is missing. Actually, I know you have. I left this note at the time I knew you'd notice. I didn't actually have to use the time machine to find out when that would be. I just know you that well: coffee, then oatmeal, then run, then shower, then fire up the time machine. I used the time when you would be in the shower. It wasn't very risky - if you were early, thered be nothing strange about your niece being in the kitchen.

Here's what I've done with the time machine so far: I've been to see Uncle John. You looked so sad when you told me that we can't change our loved one's deaths, that we can't change the past at all. But you told me he was alone when he died. The heart attack that took him in the middle of the night: he was alone.

I made sure he wasn't. I held his hand as

\section{$\rightarrow$ NATURE.COM}

Follow Futures: y @NatureFutures f go.nature.com/ mtoodm he went off into into whatever is next, which we can't reach with your time machine or Mum's stardrive. I made sure that the last thing he heard was that while he was with us, he was loved. I saw the last of Uncle John's smiles that the Universe ever contained.

Why didn't you think of doing that, Uncle Michael? Dad and Uncle John both taught me something more than you did: they taught me that you don't leave the people you love alone when they need you. That's the stuff we just don't do. To be blunt, that's bullshit.

I also went to see some woolly mammoths, because hey, who doesn't like woolly mammoths? They frolicked, and it was awesome, but I bet you knew that, because you found time for the woolly mammoths. $\mathrm{Oh}$, and I went to the first Purple Toupee show, because I'm 16, and what 16-year-old doesn't want to see her favourite band? (First shows are overrated. The band are desperate and don't have it quite together yet. You told me. I should have listened. You were right about that much, at least but seriously, Woodstock? You were too young for that cliché. I'm way too young for that cliché.)

Also I left a cryptic note at my best friend's, telling her not to worry. She will worry anyway, so I'll drop in there next week to reassure her as best I can. If you have any messages for me, you can leave them with her. (My best friend is Sarah. Come on, you should know that by now. You keep thinking it's Monica. Really, Uncle Michael. Nobody who could be best friends with Monica would ever

Then I went back to you the night after Mum's stardrive test failed and she and Dad disappeared. I bet you don't remember her, the girl on the plane who listened to you pour the whole story out, who handed you tissues and listened to how scared you were about raising your niece, how much you would miss your sister and brother-in-law. I wore a wig. That's all it took, a wig. You never knew it was me. But I was there.

I went back and encouraged Grandma to stick with the clarinet. You remember the story she tells of the older girl who bolstered her confidence when she was 12 ? That was me. I didn't even need the wig for Grandma. But I wore it for myself, the time that you didn't make it to my talent show. The time you said you couldn't make it to my talent show, and someone's big sister was the only one who said I was good. You have a time machine. What does 'couldn't make it' mean with a time machine? have stolen your time machine.)

So now I'm off to find out what happened with Mum's stardrive test. I'm going to go back to make observations until I can figure it out. Maybe I'll find Mum and Dad somewhere in the Universe, alive, waiting, trying to get back. Maybe I'll find out they died. But I will put in the time and I will find out.

When you love people, you move time and space to be there for them. When you love people and have invented a time machine, you show up. You. Show. Up. If you have to try again and again, you do it. You make sure you're there. I may be only 16, but I have that figured out.

I'll come back for you when you do too. Love,

Irene.

MARISSA LINGEN has published more than 90 short stories in venues such as Analog, Lightspeed and Tor.com. 